\title{
Relative secular variations of the Earth's magnetic field in the years 1966-2016 along the profile across the main tectonic units of Poland (Zgorzelec-Wiżajny profile)
}

\author{
Anna Wojas ${ }^{1}$, Teresa Grabowska ${ }^{2}$ \\ ${ }^{1}$ AGH University of Science and Technology, Faculty of Geology, Geophysics and Environmental Protection; \\ al. A. Mickiewicza 30,30-059 Krakow, Poland; e-mail: awojas@agh.edu.pl; ORCID ID: 0000-0001-5982-9129 \\ ${ }^{2}$ AGH University of Science and Technology, Faculty of Geology, Geophysics and Environmental Protection; \\ al. A. Mickiewicza 30, 30-059 Krakow, Poland; e-mail: mtgrabow@geol.agh.edu.pl
}

(C) 2019 Authors. This is an open access publication, which can be used, distributed and reproduced in any medium according to the Creative Commons CC-BY 4.0 License requiring that the original work has been properly cited.

Received: 11 April 2019; accepted: 10 July 2019; first published online: 9 September 2019

\begin{abstract}
The paper summarizes 50 years of research on relative local secular variations of the total magnetic intensity (TMI) along Zgorzelec-Wiżajny profile (Z-W profile) through the years 1966-2016. The Z-W profile (approximately $650 \mathrm{~km}$ length) cuts through Europe's major tectonic units, including a zone of Variscan folds in the Paleozoic platform (PP), the Trans-European Suture Zone (TESZ) and the Polish part of the East European Craton (EEC). Measurements of TMI were made at 31 sites of the profile and reduced to the base recordings at the Central Geophysical Observatory in Belsk. Based on linear approximations of relative geomagnetic field values changes in time, relative annual changes in time (relative secular variations) expressed in nanoteslas [nT] per year were calculated.

The study on relative geomagnetic field values revealed slower secular variations of the geomagnetic field in EEC as compared to those in PP and TESZ. However, they show lower amplitudes of these variations. An interesting phenomenon are rapid changes in the time of the relative values (trends) of TMI starting from the year 2000, also expressed as the relative secular variations per year, particularly visible in PP area. In the qualitative sense, relative secular variations show a correlation with the main geological units in the Polish territory and also important elements in the seismic and geothermal model of the lithosphere.
\end{abstract}

Keywords: relative local secular variations, geomagnetic field, total magnetic intensity, Palaeozoic platform, Trans-European Suture Zone, East European Craton, Poland

\section{INTRODUCTION}

The geomagnetic field changes in time and space. Long-term changes of the geomagnetic field, commonly referred to as geomagnetic secular variations (SV), are typically shown on a global scale in the form of secular variation maps. Geomagnetic secular variations are caused by magnetohydrodynamic processes taking place in the Earth's outer core and in a transition zone of the outer core and the mantle itself. The origin of geomagnetic secular variations is connected with the generation of the main magnetic field of our planet.

In the 1930s, the first research conducted on a local scale and based on long-term changes of the geomagnetic field (i.e., the secular anomalies of the Earth's magnetic field changes) was initiated (Yanovskiy 1978). It was found that processes occurring within the mantle and in the Earth's crust play the main role in the generation of local, long-term 
changes of the geomagnetic field (Abdullabekov \& Maksudov 1975). Changes (also called disturbances) on a local or regional scale, obtained from the measured values of total magnetic intensity (TMI), may be due to changes in rock magnetization, for example as the effect of stresses caused by tectonic movements (the tectonomagnetic effect) or increased seismic activity manifesting itself in the form of volcanic eruptions or earthquakes (the seismomagnetic effect). The changes in rock magnetization can also be influenced by chemical processes or changes in the thermal conditions which are taking place in the Earth's crust and also the geomagnetic field that changes over time.
In the 1950s, a thesis on the relation between local SV of the geomagnetic field intensity and geological structure was put (Zaborovskiy \& Nikitskiy 1969). In Poland, this issue was presented extensively by Małoszewski (1965).

Local changes of the Earth's magnetic field can be investigated on the basis of data obtained from: - continuous geomagnetic field observations in geophysical observatories,

- magnetic measurements in time intervals along measurement profiles,

- regular, periodic magnetic surveys at established specific measurement sites in the area of investigations.

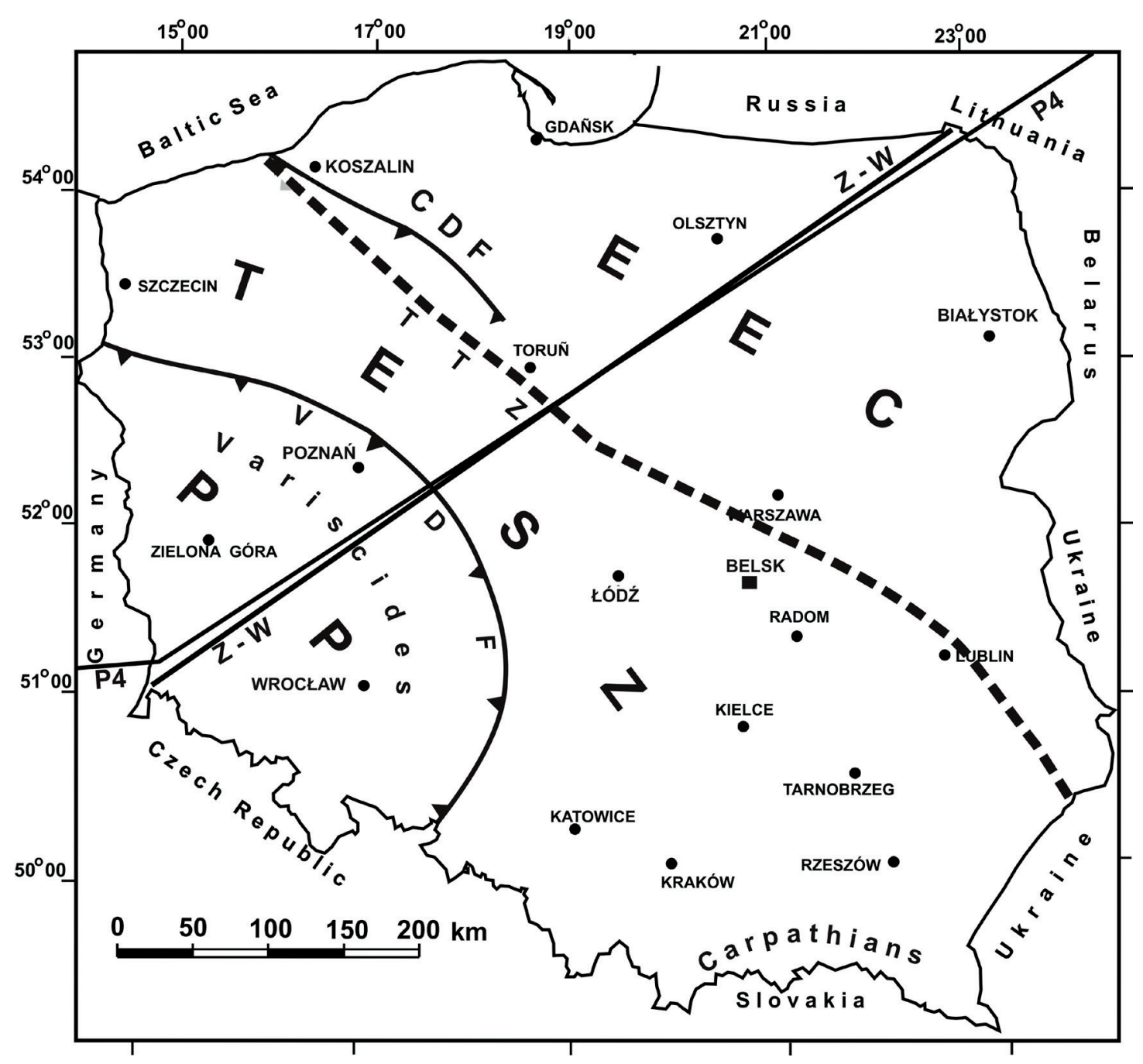

Fig. 1. Location of the Zgorzelec-Wiżajny (Z-W) profile and seismic profile P4 of the POLONAISE'97 project on the background of a simplified tectonic map of Poland (Guterch \& Grad 2016). Abbreviations: PP - Palaeozoic platform, TESZ - Trans-European Suture Zone, TTZ - Teisseyre-Tornquist Zone (Guterch \& Grad 2016), EEC - East European Craton, VDF - Variscan Deformation Front, CDF - Caledonian Deformation Front 
In Poland, research into the relationship between the local SV of the TMI and geological structure was undertaken in the 1960s by Małoszewski (1965), and is being continued in the present (Małoszewski \& Jankowski 1997, Bojdys et al. 2001, Grabowska \& Bojdys 2004a, 2004b, Bojdys \& Grabowska 2007, Bojdys et al. 2010, Wojas 2018).

From 1966 to the present day, measurements of TMI (in the context of local changes of the geomagnetic field), have been performed at annual intervals in 31 measurement sites about $12 \mathrm{~km}$ apart, located along the $\mathrm{Z}-\mathrm{W}$ profile. This profile, approximately $650 \mathrm{~km}$ long, crosses fragments of two major geological units of Europe, i.e., the Palaeozoic platform (PP) and the East European Craton (EEC), with the Trans-European Suture Zone (TESZ) constituting a contact zone (Fig. 1). The Z-W profile is located perpendicular to the regional magnetic gradient of Poland, which divides the area of the country into two magnetic provinces with different patterns of magnetic anomalies (Fig. 2).

It should be emphasized that the location of the $\mathrm{Z}-\mathrm{W}$ profile is very close to the $\mathrm{P} 4$ profile of deep seismic experiments (Fig. 1). The P4 profile, realized as a part of the international POLONAISE'97 project, enabled the construction of an integrated seismic crust and upper mantle model in the TESZ (Grad et al. 2003, Wilde-Piórko et al. 2010) and constituted an important source of information on the lithosphere structure of the EEC and the PP.

The main goal of the paper was the analysis and interpretation of relative local SV in a larger time range (1966-2016) according to taken measurements and available observatory data in relation to geological units along the Z-W profile. The emphasis was placed on the variations in the description of the dynamics and the explanation of their probable reasons.

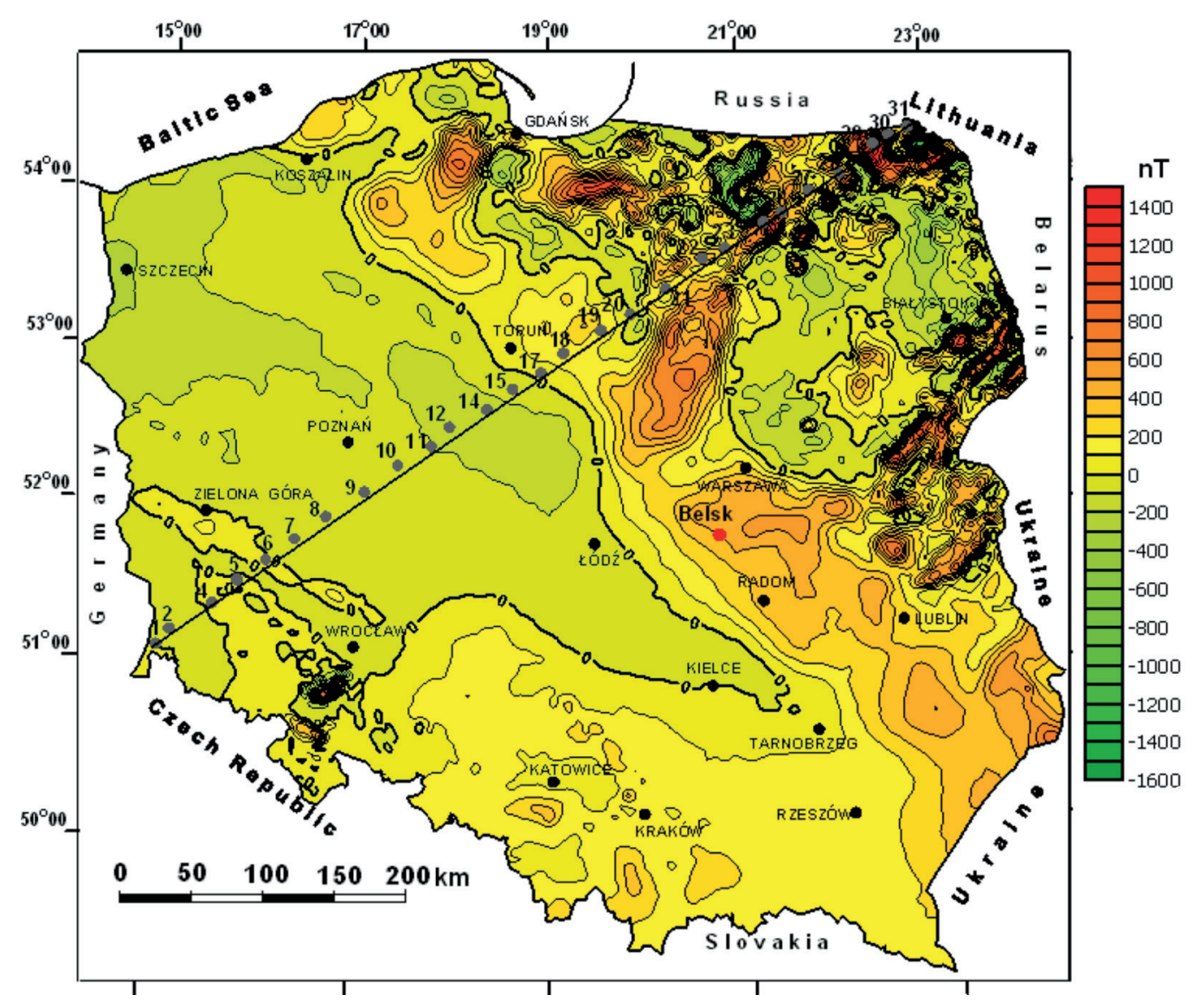

Fig. 2. Location of the measurement sites (secular points) along the Zgorzelec-Wizajny ( $Z-W)$ profile on the background of the magnetic map $(\Delta Z)$ of Poland, contour interval 100 nT, grid $5 \times 5$ km (Bojdys \& Grabowska 2007). Data source: Karaczun et al. (1978) 


\section{PAST GEOPHYSICAL SURVEYS ALONG THE Z-W PROFILE}

Marginal fragments of the two important geological units in Europe, cut by the Z-W profile, represent areas which are fundamentally different in terms of the history of their evolution and the structure of the crust and the upper mantle found therein.

The Precambrian socle of the craton (NE part of the Z-W profile), built of crystalline rocks, is overlain by a sedimentary cover. These rocks are in some places folded, metamorphosed and cut by numerous igneous intrusions (Ryka 1982, Nawrocki \& Becker 2017), something that clearly reflected in the magnetic anomalies pattern of $\mathrm{NE}$ Poland (Fig. 2).

The consolidated basement of the Palaeozoic platform (SW part of the Z-W profile) is formed by Variscan and Caledonian terranes which are covered with Permo-Mesozoic rocks. In this region (Zielona Góra-Wrocław) weak magnetic anomalies, in the form of NW-SE strips, are observed on the magnetic anomaly map of Poland. They are probably related to old magnetic Palaeozoic rocks that occurred at a depth of ca. $5 \mathrm{~km}$ (Dąbrowski \& Karaczun 1958, Dąbrowski 1969, Koblański 1989, Grabowska \& Koblański 1992).

The middle part of the $\mathrm{Z}-\mathrm{W}$ profile crosses one of the most important tectonic structures of the European continent, being the TESZ and within Poland is located the area of the Teisseyre-Tornquist Zone (TTZ).

In the light of seismic surveys (tomographic analysis of shear wave velocities $\left(V_{s}\right)$ in the mantle) of the European continent, the TESZ is a structure which is buried deep (up to ca. $200 \mathrm{~km}$ ) in the mantle (Schweitzer 1995), which splits the regions of high and low shear wave velocities (the EEC and the PP areas, respectively) (Zielhuis \& Nolet 1994).

Within the TESZ, the central part of the Permian-Mesozoic Polish basin is located. In this place, sedimentary rocks and metasediments have a significant thickness $18-20 \mathrm{~km}$.

The deep seismic soundings and passive seismic experiments carried out as a part of the international POLONAISE'97 project allowed the determination of any changes in the thickness of the crust and the lithospheric mantle, including those along the P4 profile (see Fig. 1) (Grad et al. 2003, Wilde-Piórko et al. 2010).

The lowest thicknesses of the crust, as well as of the entire lithosphere, characterize the Palaeozoic platform (the SW part of the Z-W profile), with these being about $30 \mathrm{~km}$ (the Moho boundary depth) and $90 \mathrm{~km}$ (lithosphere-asthenosphere boundary LAB depth), respectively.

Within the TESZ, in the region of Polish basin (the middle part of the $\mathrm{Z}-\mathrm{W}$ profile), the Moho boundary depth reaches about $35-38 \mathrm{~km}$, whereas the LAB's depth reaches to about $120 \mathrm{~km}$. Due to the large thickness of the sediment complex in the Polish basin, the thickness of the crust crystalline complex undergoes rapid reduction (to a dozen or so kilometres).

The maximum depths of the Moho boundary $(42-50 \mathrm{~km})$ as well as the LAB (ca. $190 \mathrm{~km})$ appear in the NE part of the Z-W profile, within the marginal part of the EEC.

It is worth noting that the velocity model of the crust and the upper mantle, constructed on the basis of deep seismic surveys is consistent with the density model generated as a result of gravity anomalies interpretation in the area of the Polish Lowlands (Grabowska \& Bojdys 2004a).

At the beginning of 1990 s, the 2D gravity modelling of the lithosphere structure along the profiles of deep seismic soundings, in the area of the Polish Lowlands showed increased rock densities for the lithospheric mantle in the EEC area in comparison to the density of rocks in the mantle itself, in the PP area (Grabowska \& Raczyńska 1991, Grabowska et al. 1992, Grabowska \& Bojdys 2004a).

The seismic model of the lithosphere along the P4 profile corresponds to its geothermal model (Majorowicz et al. 2003, Majorowicz 2004). The thickness of the thermal lithosphere of craton, determined on the basis of the $1300^{\circ} \mathrm{C}$ isotherm, is of the order of $200 \mathrm{~km}$. However, the thickness is estimated to be $100 \mathrm{~km}$ in the PP area.

Within TESZ, the results of geothermal modelling indicate a thermal differentiation of the lithosphere with the probable depth of LAB reaching $135 \mathrm{~km}$.

Along the P4 profile, the surface heat flow $\left(Q_{a v}\right)$ is changing a lot. Its value varies from 90$100 \mathrm{~mW} / \mathrm{m}^{2}$ in the PP area to $40-50 \mathrm{~mW} / \mathrm{m}^{2}$ in the 
EEC area (Majorowicz 2004, Szewczyk \& Gientka 2009). The predicted value of heat flow $\left(Q_{m}\right)$ coming from the mantle is about two times less (Majorowicz 2004). Heat flow from the mantle reaches a typical craton value of $Q_{m}=20-30 \mathrm{~mW} / \mathrm{m}^{2}$, whereas in the PP area it is in the range of 35$40 \mathrm{~mW} / \mathrm{m}^{2}$. It should be noted that the highest values of $Q_{m}$, as well as $Q_{a v}$ characterise the area of the Variscan foldings of the PP area and also the Dolsk and Middle Odra fault zones.

A clear differentiation in terms of the physical properties of the lithosphere cut by the $\mathrm{Z}-\mathrm{W}$ profile is also confirmed by the magnetotelluric results (Stefaniuk et al. 2007). A resistivity cross-section of the lithosphere indicates low resistivity values (several dozen ohms) of the rocks in the TESZ, and an increased resistivity (several hundred ohms) of rocks creating the craton socle. The resistivity of rocks in the PP area is strongly diversified and ranges between a dozen and several hundred ohms.

\section{METHODOLOGY OF FIELD MEASUREMENTS, DATA PROCESSING AND RESULTS}

Measurements of TMI (marked by the capital letter $\mathrm{T}$ in this article) at 31 sites (secular points) of the Z-W profile (Fig. 2) have been carried out from 1966 to the present at annual intervals. For diurnal changes correction, the geomagnetic field registrations measured at the same time in the Central Geophysical Observatory in Belsk were used. The calculated relative values of $\Delta T_{n, t}$ are expressed by the formula:

$\Delta T_{n, t}=T_{n, t}-T_{B e s k, t}$

where:

$n$ - the number of secular point (measurements sites),

$t$ - the time of a geomagnetic field measurement at a secular point.

Graphically presented results show the changes of the relative values $\left(\Delta T_{n, t}\right)$ over a 50 -year time interval (1966-2016) at each of the 31 secular points of the Z-W profile (Figs. 3, 4).
In the years 1966-2000, measurements of the magnetic field were carried out by means of proton magnetometers of Polish production: PMP-2, PMP-4 and PMP-7 with a resolution of 0.5 and $0.1 \mathrm{nT}$. Since 2000 to the present day, measurements have been conducted using the ENVI System proton magnetometer produced by the Canadian company SCINTREX. This device eliminates short-time disturbances of various origins (for example industrial noise) and protects the measurement with an accuracy of $0.1 \mathrm{nT}$.

The methodology for measurements along the Z-W profile was as follows: at each measurement site $(n)$ located by means of the Garmin GPS MAP 76, 60 measurements were taken per minute. The relative value of the magnetic field $\left(\Delta T_{n, t}\right)$ was determined according to the formula:

$\Delta T_{n, t}=\frac{1}{60} \sum_{1}^{60}\left(T_{o b s, n,(\tau+\Delta \tau)}-T_{B e l s k, \tau}\right)$

where:

$\tau$ - the measurement time in GMT,

$\Delta \tau$ - the time correction related to the difference in longitude between the measurement site and Belsk.

A method to determine the relative local changes of the geomagnetic field, as described in the work by Małoszewski \& Jankowski (1997), and then modified (Bojdys et al. 2001) was applied. The relative values of the magnetic field on each of the 31 measurement sites $\left(\Delta T_{n, t}\right)$ over the 50 -year time period were graphically presented (Figs. 3,4 ) and were approximated by straight lines, described by the first degree polynomials:

$W_{n}(t)=b_{n} t+a_{n}$

where $b_{n}$ - the coefficient corresponding to the line slope, define a relative local variation $b_{n}=\partial\left(\Delta T_{n}\right)$ of the geomagnetic field at the measurement site $n$ [nT/year].

It was assumed that straight lines (see Formula (3)) reflect the tendencies (so-called trends) in changes of the geomagnetic field at each of the measurement sites along the $\mathrm{Z}-\mathrm{W}$ profile in a specific, for example 50-year, time interval. 


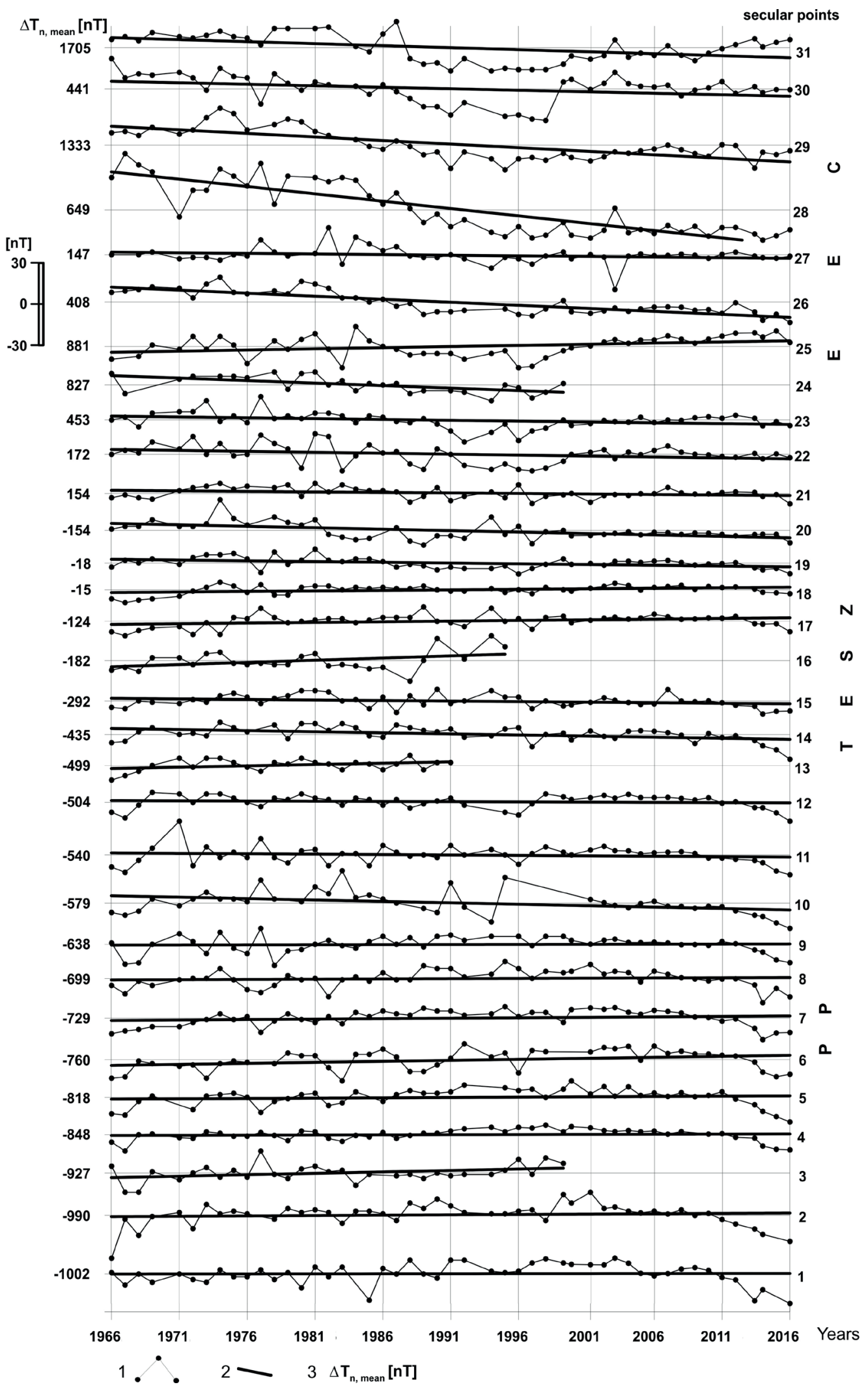

Fig. 3. Changes in the time of relative geomagnetic field values $\left(\Delta T_{n, t}\right)$ at the $n=31$ measurement sites (secular points) along the Zgorzelec-Wiżajny (Z-W) profile through the years 1966-2016. Explanations: 1 - the changes: $\Delta T_{n, t}=T_{n, t}-T_{B e l s k, t}$ over time, 2 - the linear approximations (trends) of the changes $\Delta T_{n, t}$ over time, 3 - the average relative values of the geomagnetic field (in relation to Belsk) over the 50-year time period: $\Delta T_{n, \text { mean }}=\frac{1}{50} \sum_{t=1}^{50}\left(T_{n, t}-T_{\text {Belsk, }}\right)$ 


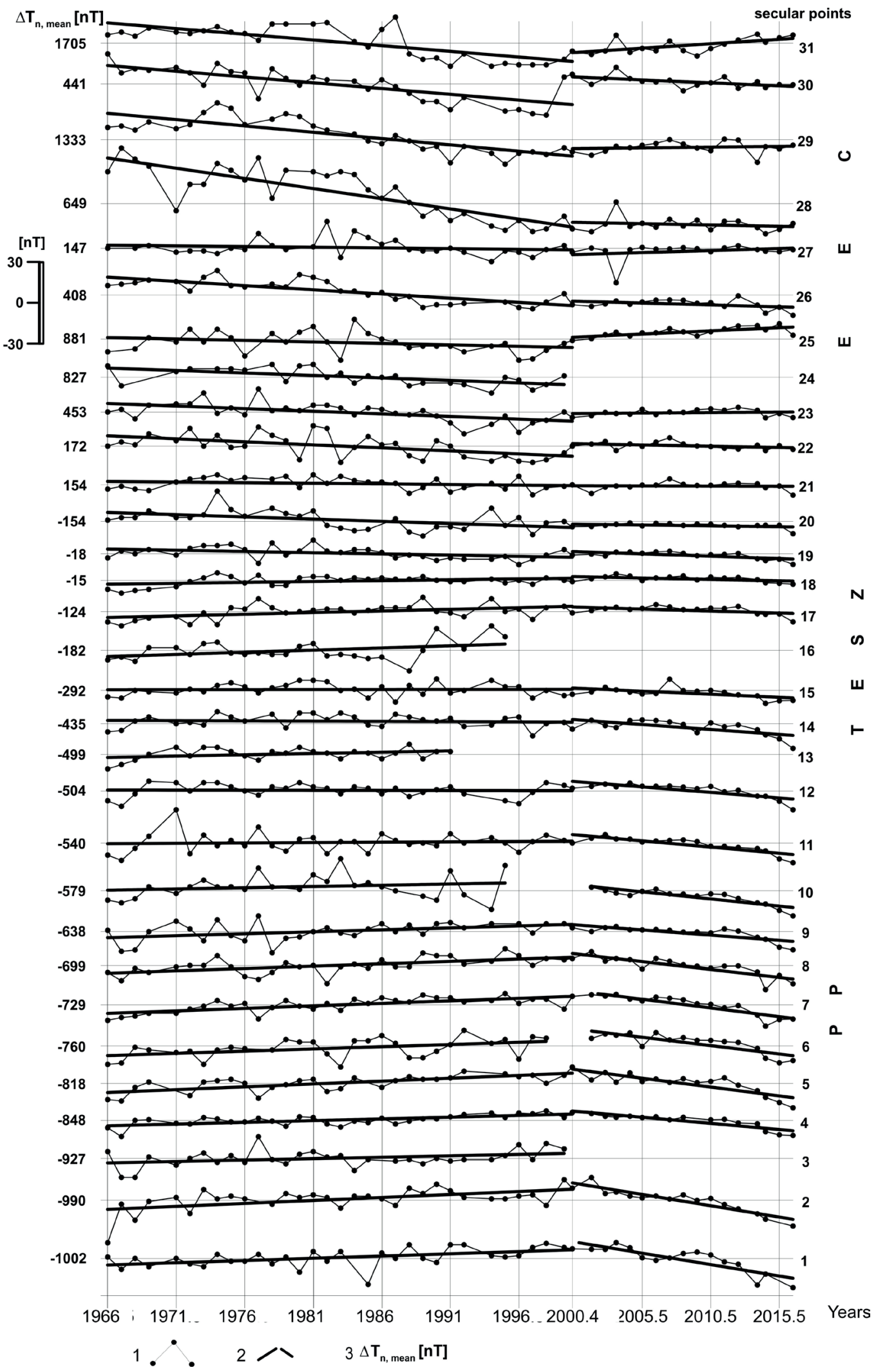

Fig. 4. Changes in the time of relative geomagnetic field values $\left(\Delta T_{n, t}\right)$ at the $n=31$ measurement sites (secular points) along the Zgorzelec-Wiżajny (Z-W) profile through the years 1966-2001 and 2001-2016. Explanations: 1 - the changes $\Delta T_{n, t}=T_{n, t}-T_{B e l s k, t}$ over time, 2 - the linear approximations (trends) of the changes $\Delta T_{n, t}$ over time 1966-2001 and 2001-2016, 3 - the average relative values of the geomagnetic field (in relation to Belsk) over the 50-year time period: $\Delta T_{n, \text { mean }}=\frac{1}{50} \sum_{t=1}^{50}\left(T_{n, t}-T_{B e l s k, t}\right)$ 
Additionally, the trends obtained were shown in relation to $\Delta T_{n \text {,mean }}$, corresponding to the average relative (in relation to Belsk) value of the geomagnetic field at a given time interval for each of the measurement sites over the 50-year time period:

$$
\Delta T_{n, \text { mean }}=\frac{1}{50} \sum_{t=1}^{50}\left(T_{n, t}-T_{B e l s k, t}\right)
$$

The relative values $\left(\Delta T_{n, t}\right)$ of the geomagnetic field at individual secular points of the profile over the 50-year time period, changing in time are shown in Figure 3. Attention should be paid to the decrease in values in relation to the average $\Delta T_{n, \text { mean }}$, as well as the change in their trends starting from around the year 2000.
For this reason, linear approximations of $\Delta T_{n, t}$ changes were made at two time intervals, i.e. 19662000 and 2000-2016 (Fig. 4). In this manner, it was possible to make calculations of the relative local secular variations $\partial\left(\Delta T_{n}\right)$ per year of the geomagnetic field over the last 15 years and previous 35 years and compare them to variations encountered in the entire 50-year-long measurement period (Fig. 5A).

In order to explain the probable causes of the relative local secular variations of the geomagnetic field along the Z-W profile, the relative local variations per year of the geomagnetic field were presented together with magnetic anomalies (Fig. 5B), and the results of deep seismic studies (Fig. 5C) as well as geothermal investigations (Fig. 5D).

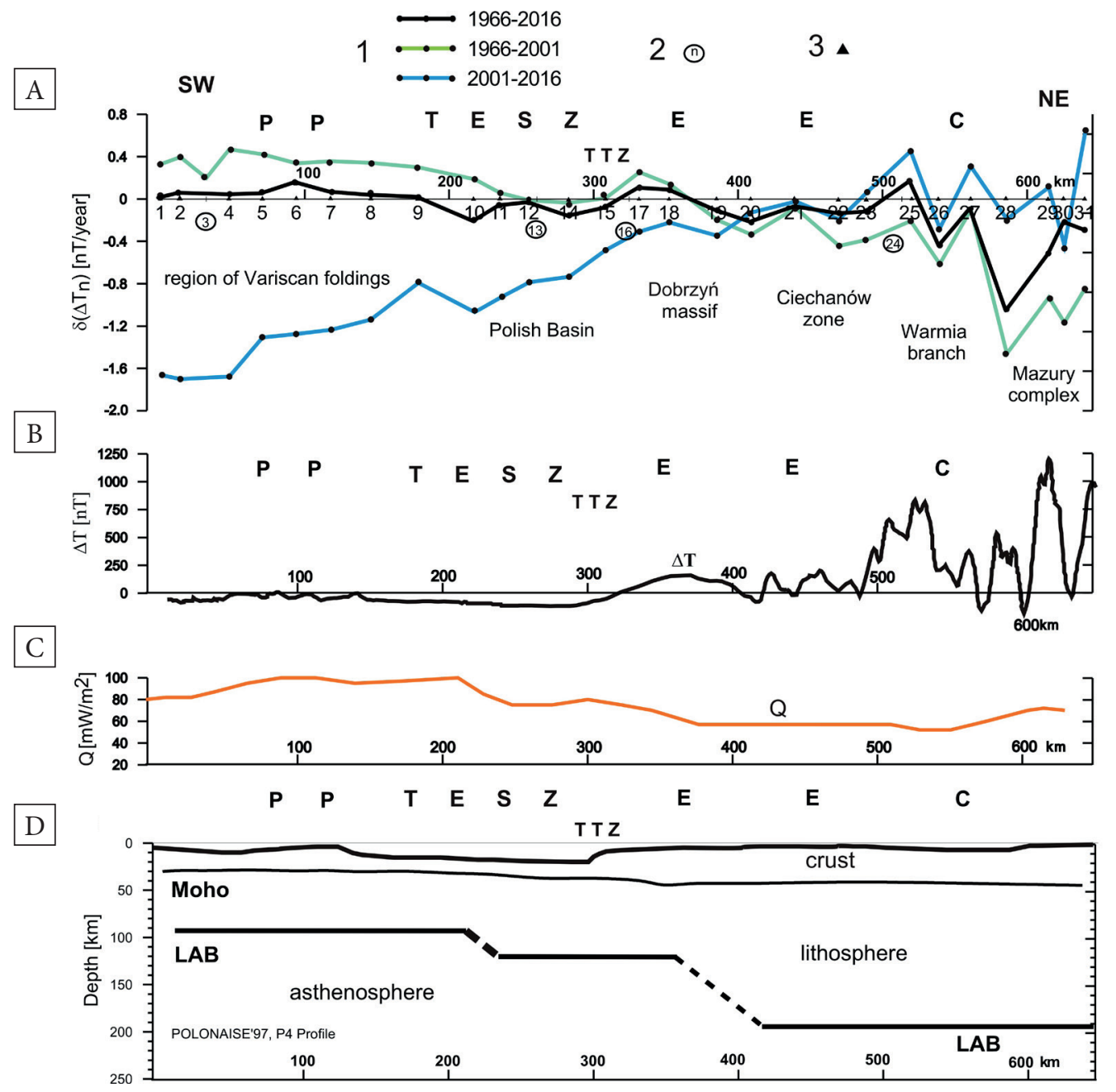

Fig. 5. Relative local secular variations $\partial\left(\Delta T_{n}\right)$ per year of the geomagnetic field along the Zgorzelec-Wiżajny $(Z-W)$ profile $(A)$ in comparison with: the total magnetic intensity (TMI) anomalies $\Delta T$ (B), surface heat flow Q (Szewczyk \& Gientka 2009) (C), seismic model of the lithosphere along the profile P4 (Grad et al. 2003, Wilde-Piórko et al. 2010) (D). Explanations: 1 - relative local secular variations $\partial\left(\Delta T_{n}\right)$ per year in three-time ranges (1966-2001, 2001-2016, 1966-2016), 2 - secular points with a lack of the continuation of measurements (for objective reasons), 3 - secular points. Abbreviations: PP - Palaeozoic platform, TESZ - Trans-European Suture Zone, TTZ - Teisseyre-Tornquist Zone, EEC - East European Craton, LAB - Lithosphere-Asthenosphere Boundary 


\section{DISCUSSION}

Analysis of the relative values $\left(\Delta T_{n, t}\right)$ of the geomagnetic field over the 50-year-long time interval at 31 measurement sites along the Z-W profile allows us to determine their characteristic features.

The lowest amplitudes of $\Delta T_{n, t}$ characterize the central part of the profile, located within the TESZ and in the area of the Polish basin. It indirectly shows the similarity of changes in time of the geomagnetic field in this region to the changes of the geomagnetic field in Belsk (Fig. 6). Higher and more diversified $\Delta T_{n, t}$ amplitudes are observed in measurement sites located on the craton, as well as on the area of the Paleozoic platform.

Another important feature of the geomagnetic field changes over time observed along the $\mathrm{Z}-\mathrm{W}$ profile, is the visible reduction of its $\Delta T_{n, t}$ relative values (amplitudes) and the appearance of different trends of their changes in time from approximately the year 2000 (Fig. 4).

The characteristic features of the time-changing relative values of $\Delta T_{n, t}$ and their linear approximations (Figs. 3, 4) are clearly visible in graphs illustrating the relative local secular variations $\partial\left(\Delta T_{n}\right)$ of the geomagnetic field, expressed in nanoteslas per year (Fig. 5A). Changes in the 1966-2016 time interval are very small, almost none $(0.0 \mathrm{nT} /$ year) for PP (secular points 1-18) and $-0.3 \mathrm{nT} /$ year for EEC (secular points 19-31) compared to the average annual change in the geomagnetic field, which reaches about $29 \mathrm{nT} /$ year in Belsk (Fig. 6), as well as similar average values for annual changes at the individual sites of the profile (Grabowska \& Bojdys 2004b).

In the cratonic area, a noticeable feature of the $\partial\left(\Delta T_{n}\right)$ - relative local variations of the geomagnetic field are their negative values. This indicates a reduction in the rate of the geomagnetic field increase in this region when compared to Belsk. It is worth noting that in this part of the profile, visible increases in the thickness of the lithosphere and the depth of LAB occurrence (Fig. 5D) are accompanied by the reduction in surface and mantle heat flow (Fig. 5C).

In addition, it should be noted that a clear differentiation of the relative local secular variations $\partial\left(\Delta T_{n}\right)$ occurred within the north-eastern section of the Z-W profile. The reasons for this phenomenon may be found in the geological structure of the crystalline basement of this part of the craton. Fragments of the large lithological units of the crystalline basement cut by the profile, such as the Warmia zone (the eastern branch of the pre-Karelian folded zone) and the Mazury complex (Ryka 1982) are composed of rocks with strong magnetic properties (Grabowska \& Bojdys 2004b). This area is also characterized by the occurrence of numerous faults, crossing the crystalline socle of the craton (Ryka 1982) and the intensification of the neotectonic movements of the Earth's crust (Kowalski \& Liszkowski 1972).

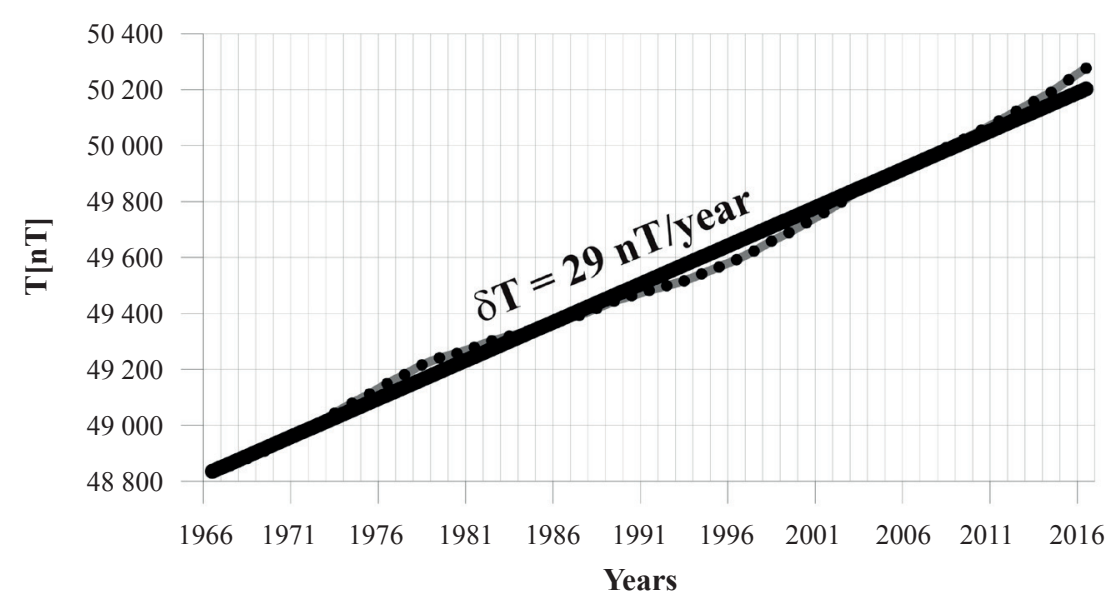

Fig. 6. Variations of the geomagnetic field intensity (T) through the years 1966-2016 at the Central Geophysical Observatory in Belsk with the mean variation $(\delta T)$ [nT/year] 
Movements of magnetic masses generate stresses, which in addition to the changing (here increasing) geomagnetic field, may cause changes in rock magnetization and, consequently, become a source of local long-term changes of the geomagnetic field (Koblański 1988a, 1988b, Bojdys et al. 2010).

On the other hand, in contrast to the craton, the Paleozoic platform is characterized by a slightly higher rate of magnetic field increase in relation to Belsk, as evidenced by the appearance of positive values of $\partial\left(\Delta T_{n}\right)$ over the time interval of 1966-2000 (Fig. 5A). In contrast to the craton, the thickness of the lithosphere in this part of the profile is twice as small as the LAB depth (Fig. 5D) and the values of the surface and mantle heat flow are twice as large (Fig. 5C).

A comparison of the relative secular variations of the geomagnetic field with units of the geological structure of Poland, and the results of deep seismic and teleseismic research, and geothermal studies (Fig. 5) allows us to present a hypothesis as to the causes of local magnetic field changes as the results of the magnetohydrodynamic processes occurring in the upper mantle (asthenosphere). The characteristics features of relative secular variations observed along the Z-W profile, such as the increase in their rate (Palaeozoic platform) and their slowdown in the craton, with significant differences in the depths of LAB occurrence and in the values of heat flow, seem to confirm this hypothesis.

Other, relative secular variations $\partial\left(\Delta T_{n}\right)$ observed over the short time interval of 2000-2016 in the area of the Paleozoic platform, should be also shown (Fig. 5A). The negative values of these changes indicate a clear slowdown in relation to Belsk of the increase rate of the geomagnetic field in this area from 2000 to the present day. It is worth noting that the moment for the appearance of these changes coincides with "the moment of a breakdown of the direction of changes in the field elements or changes of their module, which was observed in 2000" in Central Europe, and which has been presented in a paper by Welker (2007).

\section{CONCLUSIONS}

The presented results, summarizing the 50-yearold period of measurements of the geomagnetic field $(T)$ along the Zgorzelec-Wiżajny profile, allow us to state that:
1. The character of relative local, long-term changes $\left(\Delta T_{n, t}\right)$ of the geomagnetic field along the Z-W profile shows a correlation (in the qualitative sense) with the main geological units of Poland.

2. Lower values of relative local secular variations per year $\partial\left(\Delta T_{n}\right)$ of the geomagnetic field are characteristic for the area of Polish Basin, positive values are observed in the Dobrzyn massif area and their large diversification responds the regions of the Warmia Branch and Mazury complex. Relative local SV per year do not exceed $1 \%$ of the annual change of the geomagnetic field, registered in the Belsk magnetic observatory.

3. The important features of relative local secular variations per year $\partial\left(\Delta T_{n}\right)$ of the geomagnetic field are:

a) increased dynamics of local secular variations of the geomagnetic field in relation to Belsk in the time interval of 1966-2001 and the slowdown of the geomagnetic field increase in the time interval of 2001-2016 observed in the Paleozoic platform;

b) poor dynamics of within TESZ, where the geomagnetic field increase corresponds to the increase of the geomagnetic field in Belsk;

c) a stalling and differentiated local secular variations of the geomagnetic field in relation to Belsk in the area of the craton.

4. Relative local secular variations per year $\partial\left(\Delta T_{n}\right)$ of the geomagnetic field, combined with the results of a) seismic surveys, specifying changes in the thickness of the seismic lithosphere and the LAB localization along the profile, $b$ ) geothermal studies, determining changes to the surface and mantle heat flow and also the thickness of the geothermal lithosphere, allow us to hypothetically link the relative local secular variations of the geomagnetic field observed along the $\mathrm{Z}-\mathrm{W}$ profile with the activity of the magnetohydrodynamic processes taking place in the liquid part of the upper mantle. The results of these processes may be overlapped in the NE part of the profile by changes in the magnetization of the crystalline rocks of the crust, due to stresses caused by tectonic movements and the geomagnetic field changing over time. 
The paper summarises earlier and current studies on the secular variations of the geomagnetic field along the Zgorzelec-Wiżajny profile as part of the statutory research of the Faculty of Geology, Geophysics and Environmental Protection, AGH University of Science and Technology, contact no. 11.11.140.646. We thank Dr Jan Reda from the Belsk Observatory of the Polish Academy of Sciences for providing the magnetic data.

The paper was financially supported from the research subsidy no. 16.16.140.315 at the Faculty of Geology Geophysics and Environmental Protection of the AGH University of Science and Technology, Krakow, Poland, 2019.

\section{REFERENCES}

Abdullabekov K.N., Maksudov S.Kh., 1975. Variatsii geomagnitnogo polya seysmoaktivnykh regionov. Izdatel'stvo Fan, Tashkent [Абдуллабеков К.Н., Максудов С.Х., 1975. Вариации геомагнитного поля сейсмоактивных регионов. Издательство Фан, Ташкент].

Bojdys G. \& Grabowska T., 2007. Space-time analysis of the relative local secular variations of the geomagnetic field (1966-2005) along Zgorzelec-Wiżajny profile. Acta Geophysica, 55, 2, 169-181. DOI: 10.2478/s11600-007-0001-y.

Bojdys G., Grabowska T. \& Szybiński M., 2001. Zmiany wiekowe pola magnetycznego Ziemi wzdłuż profilu Zgorzelec-Wiżajny [Secular variations of the geomagnetic field along Zgorzelec-Wiżajny profile]. Geologia: kwartalnik Akademii Górniczo-Hutniczej im. Stanisława Staszica w Krakowie, 27, 2-4, 527-541.

Bojdys G., Grabowska T., Wójcik A. \& Medoń Z., 2010. Wyniki badań nad lokalnymi zmianami pola magnetycznego Ziemi na lubelskim skłonie wschodnioeuropejskiego kratonu (profil Parczew-Chełm) [Study on the relative local temporal changes of the geomagnetic field on the Lublin slope of the East European Craton (the Parczew-Chełm profile)]. Geologia: kwartalnik Akademii Górniczo-Hutniczej im. Stanisława Staszica w Krakowie, 36, 2, 155-171.

Dąbrowski A., 1969. Skały czynne magnetycznie na obszarze przedsudeckim [Magnetically active rocks in the Fore-Sudetic area]. Kwartalnik Geologiczny, 13, 4, 889-896.

Dąbrowski A. \& Karaczun K., 1958. Mapa magnetyczna Polski 1 : 200 000. Biuletyn Instytutu Geologicznego, 137, Warszawa.

Grabowska T. \& Bojdys G., 2004a. Preliminary 2D density and magnetic models of the lithosphere along seismic profile P4 of the international project POLONAISE'97 in Poland. [in:] European Geosciences Union: general assembly 2004: Nice, France, 25-30 April 2004: abstracts (Geophysical Research Abstracts, 6), EGU, Vienna [electronic document].

Grabowska T. \& Bojdys G., 2004b. Analysis of geomagnetic field along seismic profile $\mathrm{P} 4$ of the International Project POLONAISE'97. Tectonophysics, 383, 1-2, 15-28, DOI: 10.1016/j.tecto.2004.02.002
Grabowska T. \& Koblański A., 1992. Interpretation of magnetic anomalies along the Eu-3 Geotransect in Poland. Acta Geophysica Polonica, 40, 2, 175-185.

Grabowska T. \& Raczyńska M., 1991. Structure of the Earth's crust on the Polish Lowland in the light of gravimetric modelling. Publications of the Institute of Geophysics Polish Academy of Sciences, A-19, 230, 85-110.

Grabowska T., Raczyńska M. \& Dolnicki J., 1992. Interpretation of gravity anomalies along the Eu-3 Geotransect in Poland. Acta Geophysica Polonica, 40, 2, 159-173.

Grad M., Jensen S.L., Keller G.R., Guterch A., Thybo H., Janik T., Tiira T., Ylimieni J., Luosto U., Motuza G., Nasedkin V., Czuba W., Gaczyński E., Środa P., Miller K.C., Wilde-Piórko M., Komminaho K., Jacyna J. \& Korabliova L., 2003. Crustal structure of the Trans-European suture zone region along POLONAISE'97 sesmic profile P4. Journal of Geophysical Research. Atmospheres, 108, B11, 2541. DOI: 10.1029/2003JB002426.

Guterch A. \& Grad M., 2016. Struktura skorupy i górnego płaszcza Ziemi Europy - wielkie eksperymenty sejsmiczne $i$ implikacje geodynamiczne. Posiedzenie Komitetu Geofizyki PAN, Warszawa, [on-line:] www.kgeof. pan.pl/images/stories/pliki_2016/KomGeof2016-fin.pdf [access: 19.07.2019].

Yanovskiy B.M., 1978. Zemnoy magnetizm. Izdaniye 4, Izdatel'stvo Leningradskogo Universiteta, Leningrad [Яновский Б.М., 1978. Земной магнетизм. Издание 4, Издательство Ленинградского Университета, Ленинград].

Karaczun K., Karaczun M., Bilińska M. \& Uhrynowski A., 1978. Mapa magnetyczna Polski, anomalie składowej pionowej Z pola magnetycznego Ziemi 1:500 000. Wyd. Instytutu Geologicznego, Warszawa.

Koblański A., 1988a. Związek czasowych zmian pola magnetycznego z procesami tektonicznymi. Zeszyty Naukowe Akademii Górniczo-Hutniczej im. Stanisława Staszica. Geofizyka Stosowana, 1, 461-472.

Koblański A., 1988b. Badania tektonomagnetyczne w obszarze lubelskim. Zeszyty Naukowe Akademii Górniczo-Hutniczej im. Stanisława Staszica. Geofizyka Stosowana, 1, 473-481.

Koblański A., 1989. Elementy tektoniki podłoża skonsolidowanego południowej części monokliny przedsudeckiej w świetle badań magnetycznych [Tectonic elements of the consolidated basement in the southern part of Fore-Sudetic monocline in the high of magnetic studies]. Zeszyty Naukowe Akademii Górniczo-Hutniczej im. Stanisława Staszica. Geofizyka Stosowana, 5, 92-93.

Kowalski W.C. \& Liszkowski J., 1972. Współczesne pionowe ruchy skorupy ziemskiej w Polsce na tle jej budowy geologicznej [The depence between the recent vertical movements of the Eart's crust in Poland and its geological structure]. Biuletyn Geologiczny / Uniwersytet Warszawski. Wydział Geologii, 14, 5-19.

Majorowicz J.A., Cermak V., Safanda J., Krzywiec P., Wróblewska M., Guterch A. \& Grad M., 2003. Heat flow models cross the Trans-European Suture Zone in the area of the POLONAISE'97 seismic experiment. Physics and Chemistry of the Earth, Parts A/B/C, 28, 9-11, 375-391. DOI: 10.1016/S1474-7065(03)00059-7. 
Majorowicz J., 2004. Thermal lithosphere across the Trans-European Suture Zone in Poland. Geological Quarterly, $48,1,1-14$.

Małoszewski S., 1965. O zmianach wiekowych natężenia ziemskiego pola magnetycznego na ziemiach Polski oraz o ich zależności od współrzędnych geograficznych i budowy geologicznej. Zeszyty Naukowe Akademii Górniczo-Hutniczej im. Stanisława Staszica. Rozprawy, 44, 205, 1-130 [postdoctoral degree thesis].

Małoszewski S. \& Jankowski J., 1997. On secular variations of the geomagnetic field along a profile across the Teisseyre-Tornquist zone. Acta Geophysica Polonica, 45, 23-31.

Nawrocki J. \& Becker A. (ed.), 2017. Atlas geologiczny Polski. PIG-PIB, Warszawa.

Ryka W., 1982. Tektonika uskokowa cokołu krystalicznego platformy prekambryjskiej w Polsce [Fault tectonics of crystalline sockle of the Precambrian platform in Poland]. Kwartalnik Geologiczny, 26, 3/4, 545-558.

Schweitzer J., 1995. Blockage of regional seismic waves by the Teisseyre-Tornquist Zone, Geophysical Journal International, 123, 1, 260-276. DOI: 10.1111/j.1365-246X.1995. tb06674.x.

Stefaniuk M., Kosobudzka I., Wojdyła M. \& Ostrowski C., 2007. Dokumentacja badań geofizycznych. temat: Pomiary polowe magnetotelluryczne, magnetyczne i grawimetryczne wzdłuż profilu Zgorzelec-Wiżajny wraz $z$ ich przetwarzaniem i interpretacja, 2005-2007. Narod. Arch. Geol. PIG-PIB, Warszawa.

Szewczyk J. \& Gientka D., 2009. Terrestial heat flow density in Poland - a new approach. Geological Quarterly, 53, 1, 125-140.

Welker E., 2007. Zmiana pola magnetycznego Ziemi w latach 1980-2005 na przykładzie dynamicznych modeli zmian jego dwóch wybranych elementów. Prace Instytutu Geodezji i Kartografii, 53, 111, 47-63.

Wilde-Piórko M., Świeczak M., Grad M. \& Majdański M., 2010. Integrated seismic model of the crust and upper mantle of the Trans-European Suture zone between the Precambrian craton and Phanerozoic terranes in Central Europe. Tectonophysics, 481, 108-115. DOI: 10.1016/ j.tecto.2009.05.002.

Wojas A., Grabowska T. \& Mikołajczak M., 2018. Relative secular variations of the geomagnetic field along the Zgorzelec-Wiżajny profile. E3S Web of Conferences [electronic document], 35, 03001, 1-8. DOI: 10.1051/e3sconf/ 20183503001.

Zaborovskiy A.I., Nikitskiy V.Ye. (ed.), 1969. Spravochnik geofizika. 6: Magnitorazvedka. Nedra, Moskva [Заборовский А.И., Никитский В.Е. (ред.), 1969. Справочник геофизика. 6: Магниторазведка. Недра, Москва].

Zielhuis A. \& Nolet G., 1994. Shear-wave velocity in the upper mantle beneath central Europe. Geophysical Journal International, 117, 695-715. 